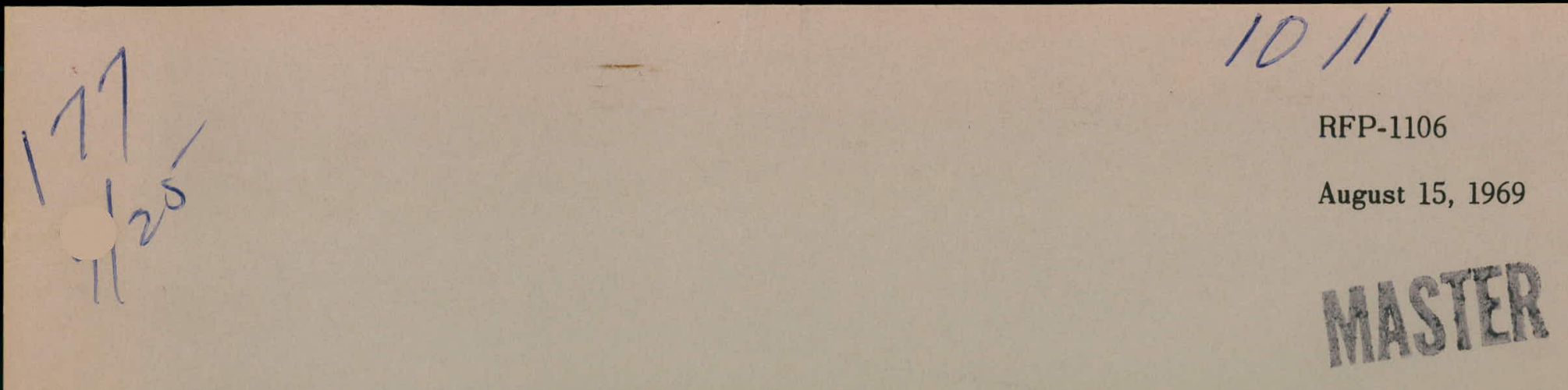




\section{DISCLAIMER}

This report was prepared as an account of work sponsored by an agency of the United States Government. Neither the United States Government nor any agency Thereof, nor any of their employees, makes any warranty, express or implied, or assumes any legal liability or responsibility for the accuracy, completeness, or usefulness of any information, apparatus, product, or process disclosed, or represents that its use would not infringe privately owned rights. Reference herein to any specific commercial product, process, or service by trade name, trademark, manufacturer, or otherwise does not necessarily constitute or imply its endorsement, recommendation, or favoring by the United States Government or any agency thereof. The views and opinions of authors expressed herein do not necessarily state or reflect those of the United States Government or any agency thereof. 


\section{DISCLAIMER}

Portions of this document may be illegible in electronic image products. Images are produced from the best available original document. 


\section{LEGAL NOTICE}

This report was prepared as an account of Government sponsored work. Neither the United States, nor the Atomic Energy Commission, nor any person acting on behalf of the Commission:

A. Makes any warranty or representation, expressed or implied, with respect to the accuracy, completeness, or usefulness of the information contained in this report, or that the use of any information, apparatus, method, or process disclosed in this report may not infringe privately owned rights; or

B. Assumes any liabilities with respect to the use of, or for damages resulting from the use of any information, apparatus, method, or process disclosed in this report.

As used in the above, "person acting on behalf of the Commission" includes any employee or contractor of the Commission, or employee of such contractor, to the extent that such employee or contractor of the Commission, or employee of such contractor prepares, disseminates, or provides access to, any information pursuant to his employment or contract with the Commission, or his employment with such contractor.

Printed in the United States of America

Available from

Clearinghouse for Federal Scientific and Technical Information National Bureau of Standards, U. S. Department of Commerce

Springfield, Virginia 22151

Price: Printed Copy $\$ 3.00$; Microfiche $\$ 0.65$ 
RFP-1106

UC-38 ENGINEERING AND EQUIPMENT

TID-4500 - 54th Ed.

\title{
WELDABILITY OF OXYGEN-FREE, BORON-DEOXIDIZED AND DEOXIDIZED LOW PHOSPHORUS COPPER
}

\author{
Eldon D. Brandon
}

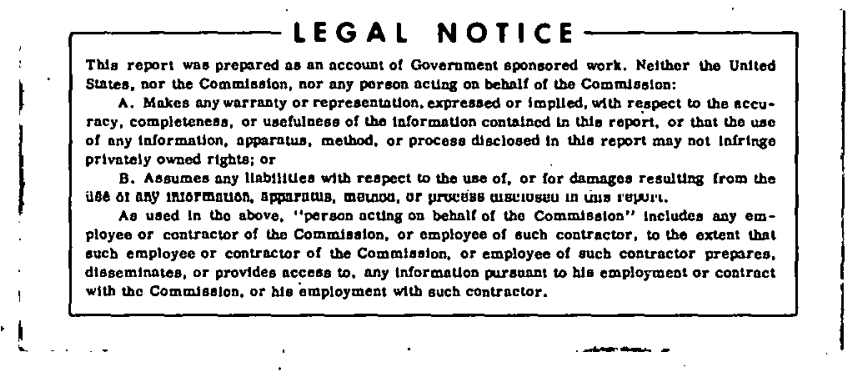
THE DOW CHEMICAL COMPANY
ROCKY FLATS DIVISION
P. O. BOX 888
GOLDEN, COLORADO 80401

Prepared under Contract AT(29-1)-1106

for the

Albuquerque Operations Office

U. S. Atomic Energy Commission 
RFP-1106 


\section{CONTENTS}

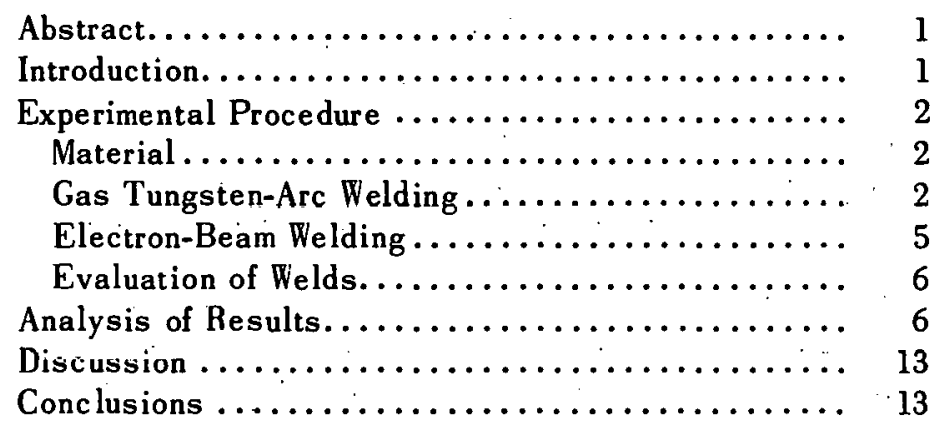




\section{ACKNOWLEDGMENTS}

Appreciation and thanks are expressed to J. K. Lynch

for his assistance in the statistical portion of the report; and to L. S. Hines who performed the welding. R. S. Bray of Anaconda American Brass Company in Waterbury, Connecticut, supplied the boron-deoxidized and deoxidized low phosphorus materials. 


\title{
WELDABILITY OF OXYGEN-FREE, BORON-DEOXIDIZED AND DEOXIDIZED LOW PHOSPHORUS COPPER
}

\author{
Eldon D. Brandon
}

\begin{abstract}
The study was designed to e valuate the weldability of materials and to investigate methods of minimizing weld porosity in such materials as oxygen-free (Alloy 102), boron-deoxidized (Alloy 109), and deoxidized low phosphorus (Alloy 120) copper. Square-butt, fully penetrated welds were made using flat, 0.024 - and 0.030 -inch thick coupons. In pressurized gas tungsten-arc welding, the variables were chamber pressure, number of welding passes, and type of shielding gas. In the second process, electron-beam welding, only the number of passes were varied.
\end{abstract}

When welded under identical conditions, welds in the boron-deoxidized (Alloy 109) copper contained less porosity. The material was, therefore considered more weldable. However by the use of proper welding parameters, sound welds were produced in all materials.

The most influential variable in affecting weldmetal porosity related to the number of welding passes made. Particularly with oxygen-free copper, the amount of porosity was reduced by increasing the number of welding passes (up to five). With all materials, the most porous welds were produced using one pass. Four passes were optimum for the boron-de oxidizcd (BD) copper while the soundness continued to improve with up to five passes for the oxygen-free (OF) and deoxidized low phosphorus (DLP) copper.

Argon and helium shielding gases were evaluated for their ability to produce sound welds. For OF copper, helium was the preferred gas. For BD copper at chamber pressures of 20 pounds per square inch gauge and below, argon was preferred: For DLP copper, the gases produced approximately equivalent welds.

Chamber pressure was a less significant variable. With OF copper, the weldability increased with chamber pressure. Chamber pressure was not significant with either BD or DLP copper.

\section{INTRODUCTION}

Copper does not exhibit the excellent weldability of many common materials. The primary defects associated with the welding of copper are gas porosity and cracks in the welds. The control of these defects has been to use a deoxidized filler metal, usually a phosphorus- or tin-bearing copper. Unfortunately, the continuity of mechanical properties, of thermal and electrical conductivities, and of corrosion resistance is not maintained across a weld of dissimilar filler and base metals. Also in thin sections where no filler is employed, a method of eliminating the formation of weld-metal defects is not a vailable.

Of the various copper alloys, oxygen-free copper has particular interest because of its good conductivity and its low rate of work hardening. Oxygen-free copper (classified by the Copper Development Association of New York City as No. 102) can be melted and cast in a reducing atmosphere to reduce the oxides. The remaining oxygen is minimal and no deoxidizers are present in the cast product. The oxygen-free coppers have the same general mechanical properties as oxygenbearing coppers, but exhibit more uniform properties. The absence of copper oxide slightly improves the cold working characteristics over that of oxygen-bearing copper. Such uniform behavior is particularly important in deep-drawing and forming operations.

Deoxidized copper may contain one or more elements such as phosphorus to act as deoxidizers. Boron is sometimes used to a void the slight reduction in the conductivity characteristic of phosphorus-rontaining ropper.

A detailed study was designed to evaluate the weldability and investigate various possible methods of minimizing weld defects in oxygenfree (OF), boron-deoxidized (BD), and deoxidized low phosphorus (DLP) copper. The study was 
directed toward conditions in which filler metal would not be employed, such as in the welding of thin sections.

Gas tungsten-arc (GTA) and electron-beam welding processes were chosen for consideration because of their applicability to thin sections. The levels of porosity resulting from the se two welding processes were compared and used as a bas is for establishing weldability.

\section{EXPERIMENTAL PROCEDURE .}

The weldability of the three copper materials was determined by butt-welding two copper strips together, using various combinations of specific parameters. 'Ihe welds were then radiographed and rated, using a rating system based on the amount of porosity in the weld zone.

The five variables and their limits of investigation were as follows:

\section{Process Gas Tungsten-Arc (GTA) and Electron Beam}

2. Material (copper) Alloy 102 (oxygen-free) Alloy 109 (boron-deoxidized) Alloy 120 (deoxidized low phosphorus)

3. Number of Welding Passes

1 to 5

4. Chamber Pressure

0 to 40 pounds per square inch gauge (psig) pressure (GTA only)

5. Type of Shielding Gas

\section{Argon and Helium (GTA only)}

Material:

Material thickness and chemical analyses of the three copper alloys are given in Table I.

The copper was procured in coil and sheet form. For the electron-beam welding, 1 by 5 -inch coupons were used; and for GTA welding, 2 by 7 -inch coupons were used. The coupons were machined
TABLE I. Composition and Thickness of Materials.

Thickness Oxygen Boron Sulphur Phosphorus (parts per million, typical values)

\begin{tabular}{|c|c|c|c|c|c|}
\hline $\begin{array}{l}\text { Oxygen- } \\
\text { Free (OF) }\end{array}$ & 0.024 & 5 & 0 & $<5$ & $<5$ \\
\hline \multicolumn{6}{|l|}{ Boron } \\
\hline \multicolumn{6}{|l|}{ Deoxidized Low } \\
\hline Phosphorus (DL,P) & 0.021 & & & 5 & 50 \\
\hline
\end{tabular}

along the long edges to permit uniformly good fit-up for welding:

Before welding, the coupons were cleaned with acetone followed by bright dip etching in a phnsphnric-acetic-nitric acid and water solution. The coupons were then rinsed in hot tap water and dried with acetone and forced air. After cleaning, the coupons appeared lustrous and stain-free.

\section{Gas Tungsten-Arc Welding:}

All gas tungsten-arc welding was conducted in a vacuum-pressure chamber. The chamber, fixture, and controls shown in Figure 1 were employed for the GTA welding. During operation the chamber was evacuated to 0.1 torr and then backfilled with argon or helium to the test pressure. The resulting impurities remaining in the chamber were approximately 10 parts per million (ppm) hydrogen, 400 ppm nitrogen, and 100 ppm oxygen. The welding operation was automatically sequenced so that the highfrequency arc initiation, gas flow, and part movement were started when the weldestrart huttinn was depressed. Both automatic and manual voltage controls were employed. During multiple-pass welding, a 10-minute interpass cooling time was used.

A horizontal platen-type fixture, having a grooved stainless steel backing bar and stainless steel hold-down bars, was used, The fixture, shown in Figure 2, traversed under the stationary GTA torch. A copper hacking bar was initially tried, but excessive underbead reinforcement often fused the coupons to the bar. With the stainless steel bar, cuntrol of weld penetration also was more consistent.

The procedure used for the GTA welding is given in Table II.

For all GTA welds, a 15 cubic feet per hour (cfh) gas flow (argon or helium) was used through the torch. This improved the stabilization of the arc; 


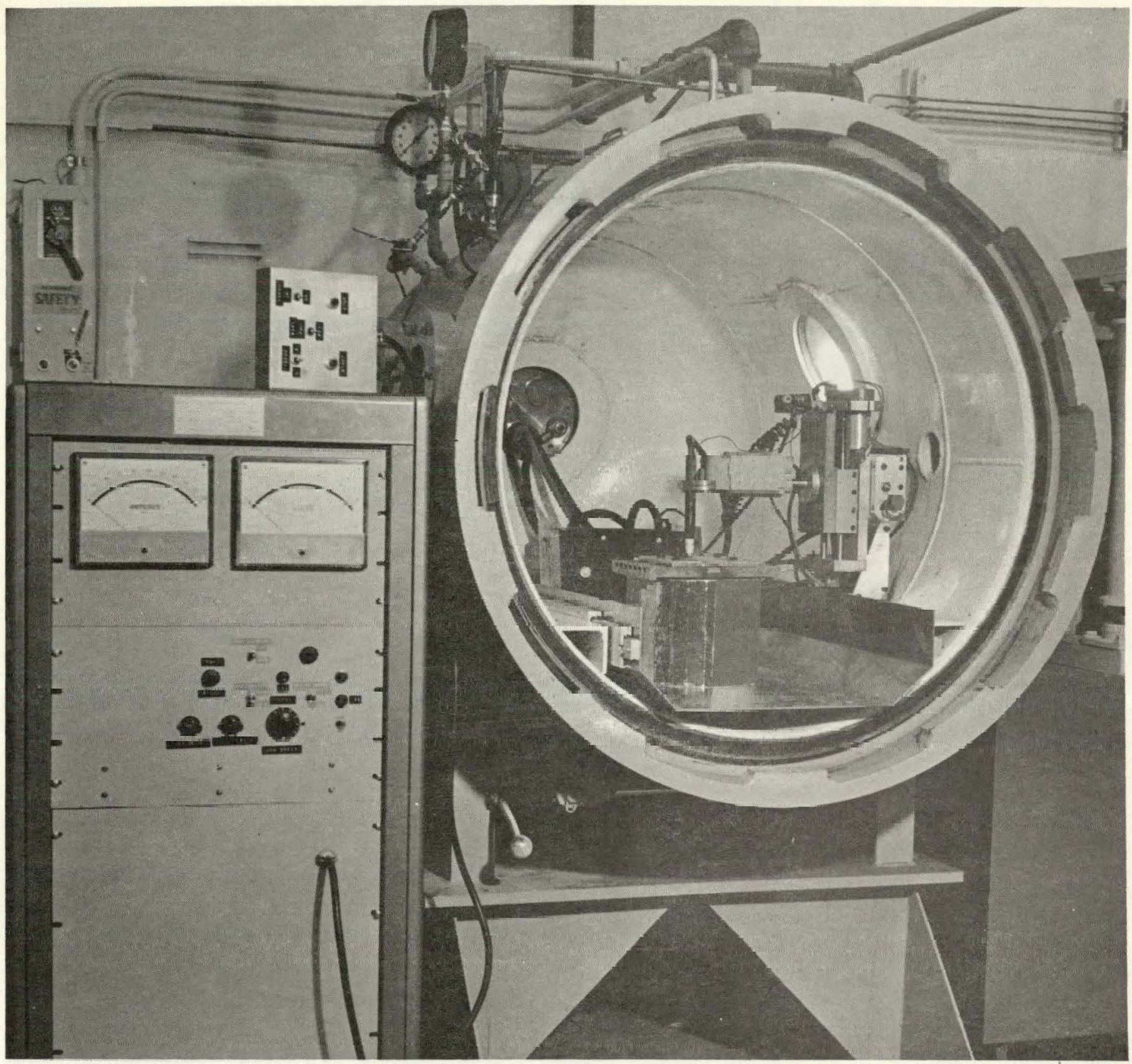

FIGURE 1. Gas Tungsten-Arc Welding System.

particularly at low (0 to 10 psig) chamber pressure. The same gas was used through the torch as in the chamber.

Because of the higher temperature (and voltage) of the arc in helium, the current was decreased to approximately half that of the argon arc for equivalent penetration. It was also necessary to increase the travel speed to prevent burn-through. For all materials, complete penetration of the joint was used as the criterion in selecting welding parameters. 


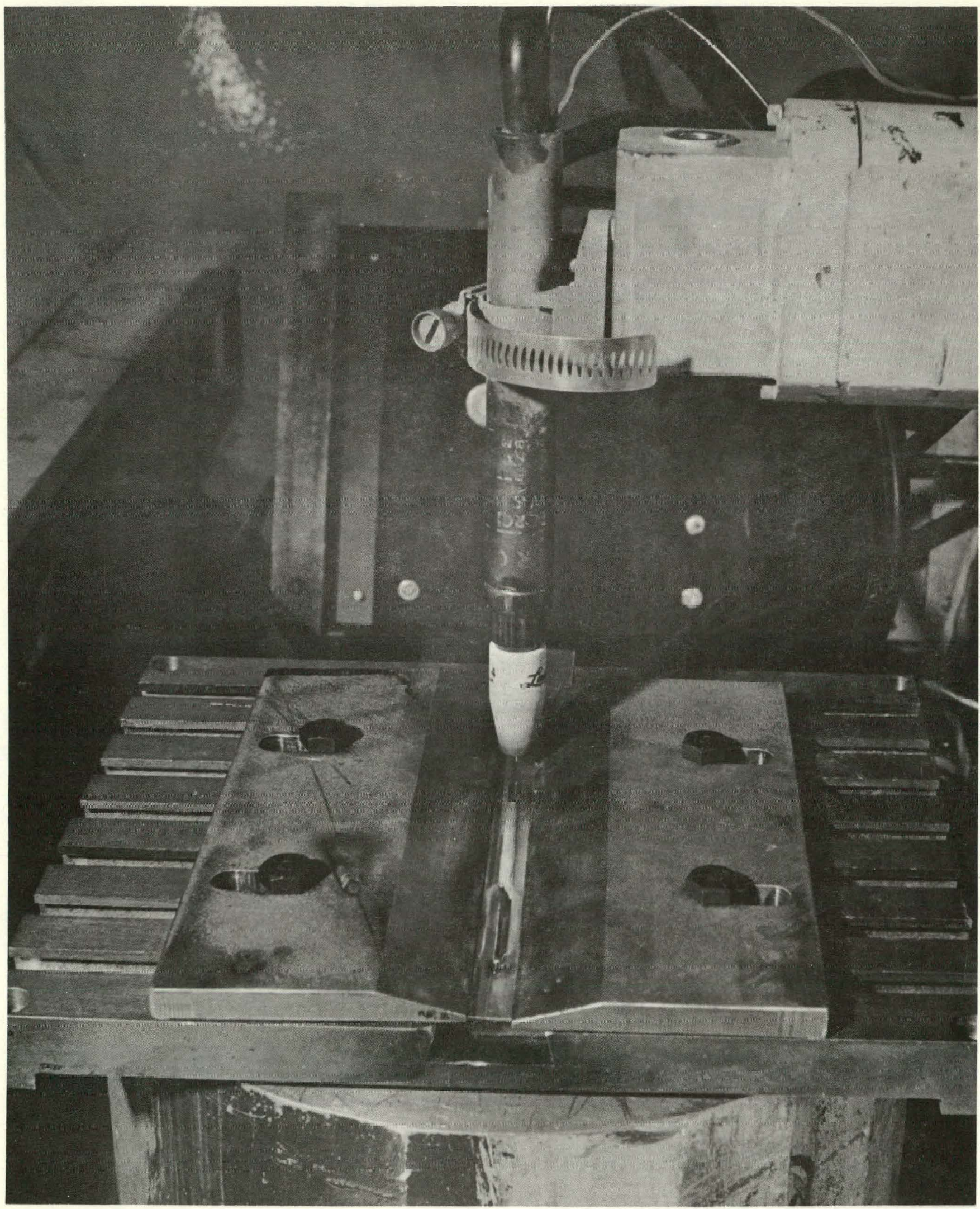

$13163-4$

FIGURE 2. Fixture Used for Gas Tungsten-Arc Welding. 
TABLE II. Procedure Used for Gas Tungsten-Arc Welding of Copper.

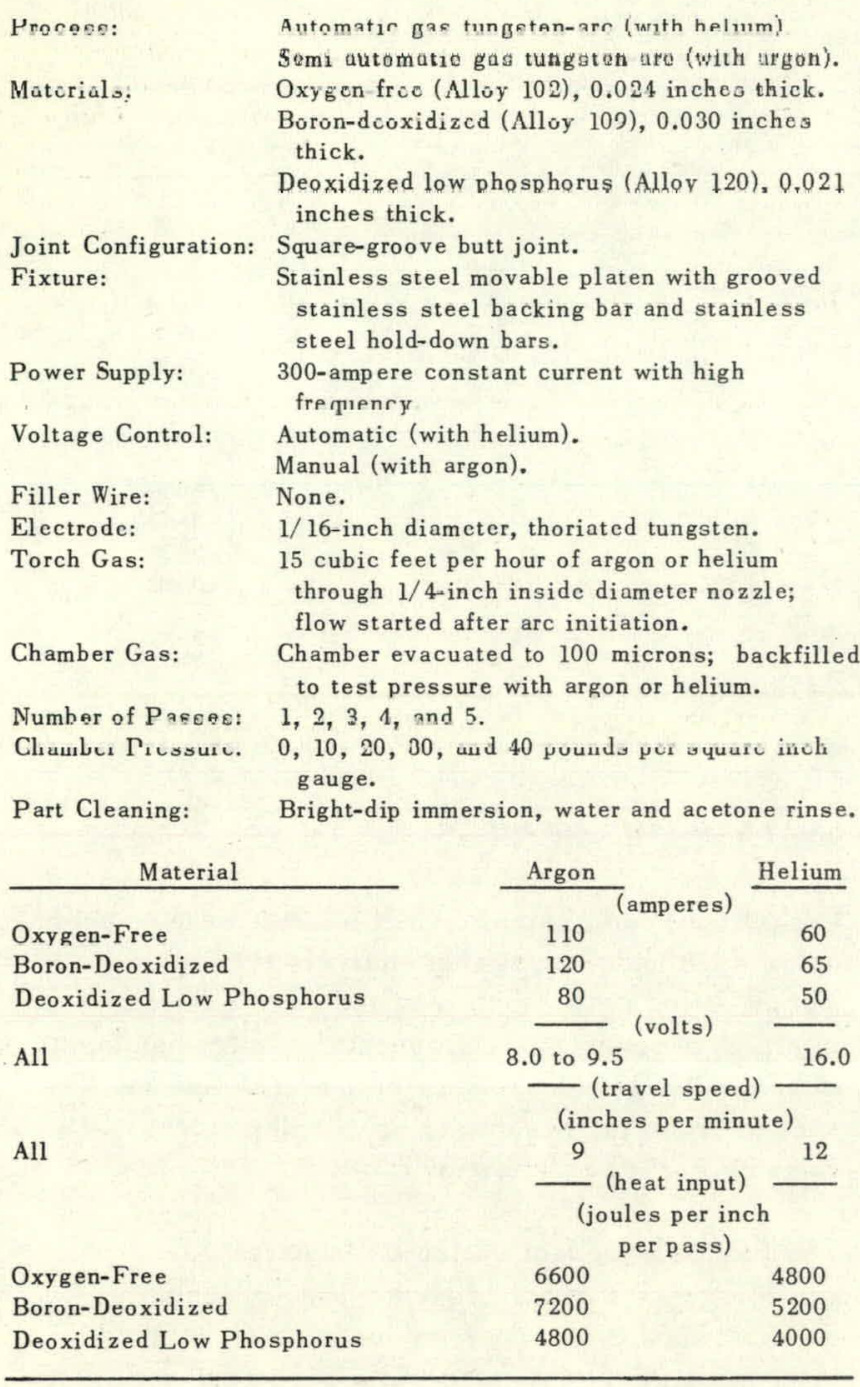

\section{Electron-Beam Welding:}

The chamber, fixture, and controls shown in Figure 3 were used for the electron-beam welding. During operation, the parts were placed in the fixture positioned vertically beneath the electronbeam gun. The chamber was then evacuated to $5 \times 10^{-5}$ torr for welding.

A low power electron-beam gun, operating at approximately 13 kilovolts and 30 milliamperes, was used.

The coupons were clamped in a stainless steel platen-type fixture having stainless steel holddown bars. For the oxygen-free copper, a grooved stainless steel backing bar was used. Because of difficulty in controlling penetration when a backing bar was used, the backing bar was eliminated for

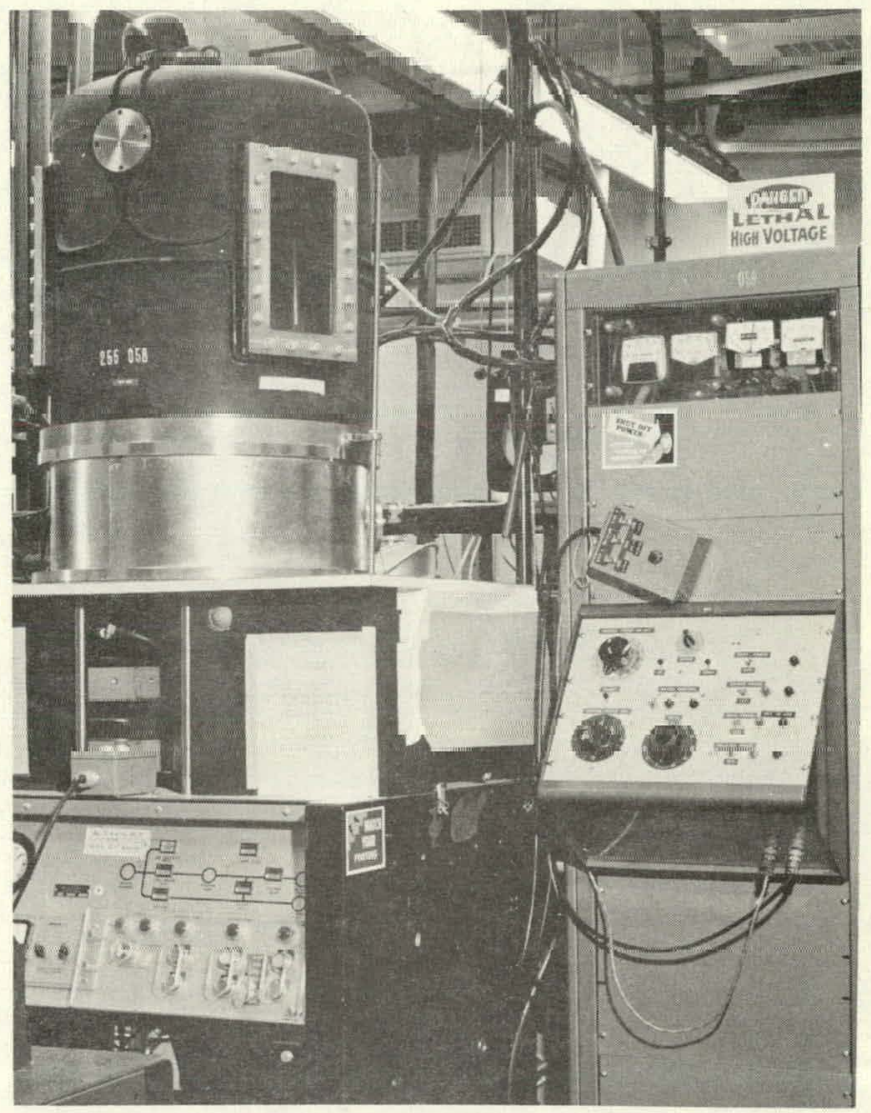

$13163-5$

FIGURE 3. Electron-Beam Welding System.

the BD copper. Also, substantial upset was experienced during the electron-beam welding. This was minimized by reducing the clamping force on one of the hold-down bars. The one coupon was thereby permitted to move laterally resulting in less vertical upset at the weld between the holddown bars. ${ }^{1}$ No electron-beam welding was performed on the DLP copper. The parameters for the electronbeam welding are given in Table III.

In welding the oxygen-free copper, the beam current was automatically controlled. It was manually controlled for the boron-deoxidized copper. Manual control permitted the operator to decrease the heat input during welding to prevent burn-thro'igh as the heat accumulated in the coupons and fixture. As with the GTA welding, a 10-minute interpass cooling period was used.

\footnotetext{
${ }^{1}$ More recent experience has shown that by maintaining a lateral force during welding, the level of porosity is reduced. However, the upset may be more pronounced.
} 
TABLE III. Parameters for Electron-Beam Welding Copper.

\begin{tabular}{|c|c|c|c|c|c|}
\hline Material & $\begin{array}{l}\text { Number } \\
\text { of } \\
\text { Passes }\end{array}$ & $\begin{array}{c}\text { Beam } \\
\text { Voltage } \\
\text { (kilovolts) }\end{array}$ & $\begin{array}{c}\text { Beam } \\
\text { Current } \\
\text { (milliamperes) }\end{array}$ & $\begin{array}{l}\text { Travel } \\
\text { Speed } \\
\text { (inches per } \\
\text { minute) }\end{array}$ & $\begin{array}{l}\text { Heat } \\
\text { Input } \\
\text { (joules per inch } \\
\text { per passs) }\end{array}$ \\
\hline \multicolumn{6}{|l|}{ Oxygen-Free } \\
\hline (0.024 inches) & $\begin{array}{l}1 \\
2 \\
3 \\
4\end{array}$ & $\begin{array}{l}13 . \\
13 . \\
13 . \\
13 .\end{array}$ & $\begin{array}{l}30 \\
30 \\
20 \\
30\end{array}$ & $\begin{array}{l}8.8 \\
8.8 \\
8.6 \\
8.4\end{array}$ & $\begin{array}{l}2660 \\
2660 \\
2720 \\
2790\end{array}$ \\
\hline \multicolumn{6}{|c|}{ Boron-Deoxidized } \\
\hline (0.030 inches) & $\begin{array}{l}1 \\
2 \\
3 \\
4\end{array}$ & $\begin{array}{l}12.5 \\
12.5 \\
12.5 \\
12.5\end{array}$ & $\begin{array}{l}30 \text { to } 40 \\
30 \text { to } 40 \\
30 \text { to } 40 \\
30 \text { to } 40\end{array}$ & $\begin{array}{l}7.2 \\
7.2 \\
7.2 \\
7.2\end{array}$ & $\begin{array}{l}3650 \\
3650 \\
3650 \\
3650\end{array}$ \\
\hline
\end{tabular}

\section{Evaluation of Welds:}

After welding, the copper coupons were radiographed using 125 kilovolts, 4 milliampere-minutes, 4-foot, source-to-work distance, and a Type-M film. The radiographs were then visually examined and the welds rated, based on the amount of porosity present. A standard was made by selecting seven radiographs showing different levels of porosity. A completely sound weld was assigned a value of 6 , and the most porous weld was assigned a value of 0 . The remaining welds were assigned intermediate numbers. The completed standards, using prints made from the radiographs, are given in Figure 4. The remaining welds were rated according to the standards noted.

Because of the irregular distribution and size of porosity, the ratings are not absolute. Rather, the tabulated values could be considered accurate to plus or minus one rating number. This does not detract from the value of the results; the trends indicated by the analysis of the data remain valid.

The ratings of the GTA welds are tabulated in Table IV. Each number represents one coupon. At several combinations, more than one coupon was welded. This provided information of reproducibility which will be discussed later.

The ratings of the electron-beam welds are given in Table V. Two coupons were welded at each combination of passes and material making a total of 16 welds.

\section{ANALYSIS OF RESULTS}

For purposes of analysis, the raw data were treated using a multiple-regression analysis technique. ${ }^{2}$ The modified data which resulted were easier to interpret because the experimental scatter had been eliminated. Also by this technique, the amount of variability in ratings due to each independent variable could be determined.

The four independent variables (material, shielding gas, number of passes, and chamber pressure) and their cross products could be used in an equation of the form:

$$
\begin{aligned}
r=B_{0} & +B_{1} X_{1}+B_{2} X_{2}+B_{3} X_{3}+B_{4} X_{4} \\
& +B_{12} X_{1} X_{2}+B_{13} X_{1} X_{3}+B_{14} X_{1} X_{4} \\
& +B_{23} X_{2} X_{3}+B_{24} X_{2} X_{4}+B_{34} X_{3} X_{4} \\
& +B_{11} X_{1}{ }^{2}+B_{22} X_{2}{ }^{2}
\end{aligned}
$$

The value, $r$, is the calculated rating at each combination of primary variable, $X_{1}, X_{2}, X_{3}$, and $X_{4}$. This theoretical value, $r$, may be slightly different from the raw data values because of the averaging effect of the quadratic equation. The trends or effects of varying the parameters, however, are emphasized, and the blank spaces where no welds were made can be filled in.

\footnotetext{
${ }^{2}$ N. R. Draper and H. Smith. Applied Regression Analysis. John Wiley and Sons, Inc., New York. 1966.
} 


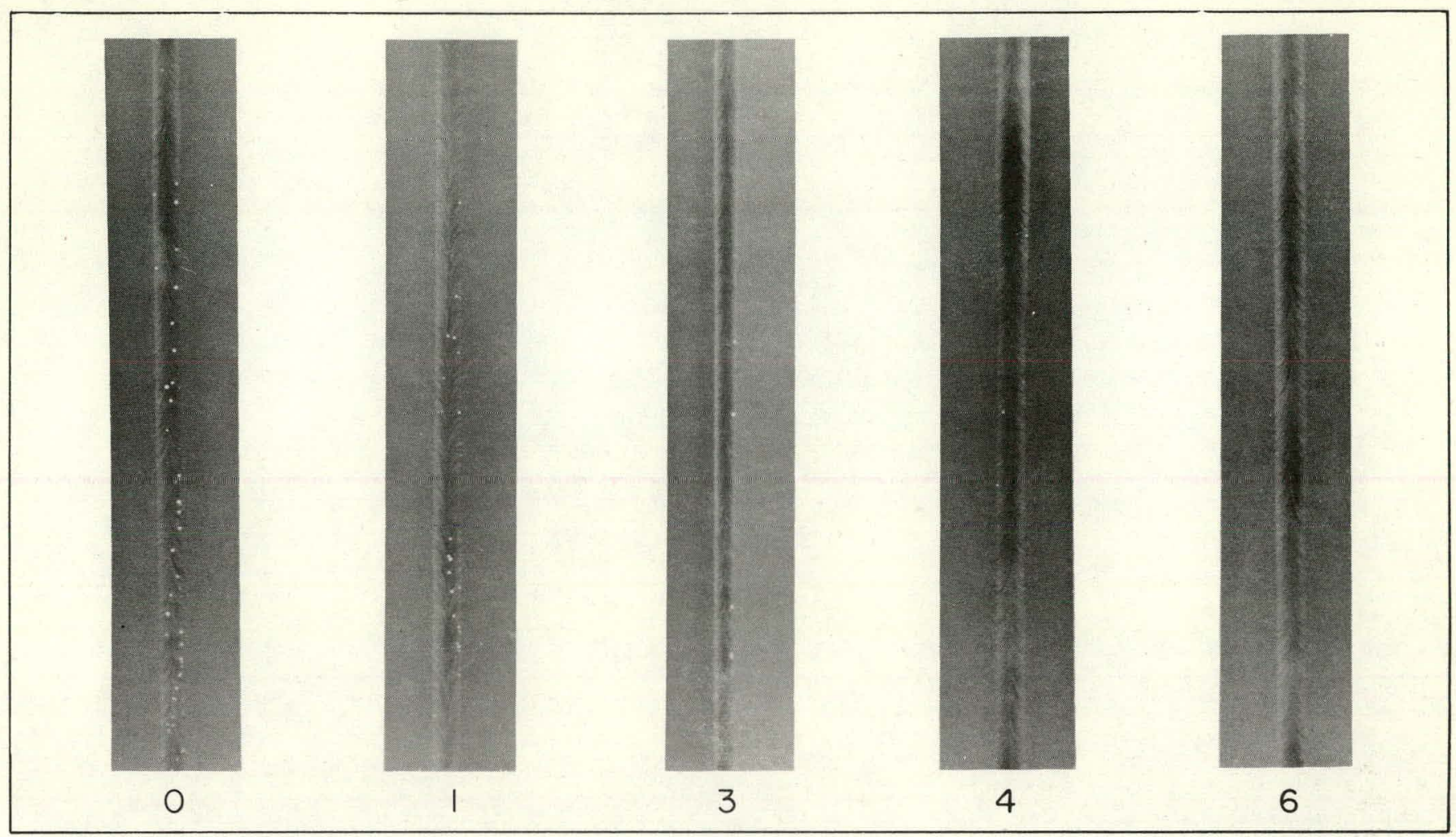

FIGURE 4. Standard for Rating Weld-Metal Porosity.

TABLE IV. Actual Rating of Coupons, Gas Tungsten-Arc Welds.

\begin{tabular}{|c|c|c|c|c|c|c|c|c|c|c|c|c|c|c|c|c|c|}
\hline \multirow{2}{*}{$\begin{array}{c}\text { Number } \\
\text { of Passes } \\
\end{array}$} & \multirow[b]{2}{*}{ Gas } & \multirow{2}{*}{$\begin{array}{c}\text { Chamber } \\
\text { Pressure } \\
\text { (psig) } \\
\text { Material } \\
\end{array}$} & $\Longrightarrow$ & 0 & & \multicolumn{3}{|c|}{10} & \multicolumn{3}{|c|}{20} & \multicolumn{3}{|c|}{30} & \multicolumn{3}{|c|}{40} \\
\hline & & & $\rightarrow \mathrm{OF}$ & $\mathrm{BD}$ & DLP & $\mathrm{OF}$ & $\mathrm{BD}$ & DLP & OF & $\mathrm{BD}$ & $\underline{\text { DLP }}$ & OF & $\mathrm{BD}$ & DLP & OF & $\mathrm{BD}$ & $\overline{D L P}$ \\
\hline \multirow[t]{2}{*}{1} & Argon & & 0,2 & 5 & 4 & 0 & 5 & & 4 & 5 & 2 & 5 & 4 & & 1 & 5 & 4 \\
\hline & Helium & & 3 & 5 & 4 & 0 & 6 & & 1 & & 3 & 6 & & & 4 & 5 & 5 \\
\hline \multirow[t]{2}{*}{2} & Argon & & 0 & 6 & & 0 & 5 & & 5 & 5 & & 4 & 5 & & 5 & 6 & \\
\hline & Helium & & $5,5,5$ & 6 & & 1 & 6 & & 0 & 6 & & 5 & 6 & & 3,6 & 5 & \\
\hline \multirow[t]{2}{*}{3} & Argon & & 3 & 6 & 5 & & & & 3 & 6 & 3 & & & & & & 3 \\
\hline & Helium & & 5 & 6 & 4 & & & & 6 & 6 & 5 & & & & & & 5 \\
\hline \multirow[t]{2}{*}{4} & Argon & & 1,1 & 6,5 & & 4 & 6 & & 5 & 6 & & 3 & 6 & & 5 & 6 & \\
\hline & Helium & & $6,4,3,4$ & 5,6 & & 4 & 6 & & 3,5 & 6,6 & & 5 & 6 & & 5,6 & 6 & \\
\hline \multirow[t]{3}{*}{5} & Argon & & 1 & 6 & 6 & & & & 4 & 6 & 5 & & & & & & 5 \\
\hline & Helium & & 5 & 6 & 4 & & & & 5 & 6 & 6 & & & & & & 5 \\
\hline & & & & & $\begin{array}{c}\mathrm{OF} \\
\mathrm{BU} \\
\mathrm{DLP} \\
\mathrm{psig}\end{array}$ & $\begin{array}{l}\text { oxye } \\
\text { boro } \\
\text { deox } \\
\text { pour }\end{array}$ & 1-fre & zed & $\mathrm{nch}$ & auge & & & & & & & \\
\hline
\end{tabular}


TABLE V. Actual Ratings of Electron-Beam Welds.

Number

$$
\text { of }
$$

$\underline{\text { Passes }}$

$\begin{array}{ll}1 & 1,2 \\ 2 & 3,3 \\ 3 & 1,5 \\ 4 & 5,5\end{array}$

The values of the coefficients $(B)$ were determined by using the raw data in a multiple linear-regression analysis. The coefficients and the assigned values of the independent variables are given in Tables VI and VII.

'I'he calculated ratings of the GTA welds are tabulated in Table VIII.

As an aid to interpretation of the calculated ratings given in Table VIII, Figure 5 is presented. The rating numbers have been grouped into five sets with each set assigned a shade of gray ranging from white to black. The white squares represent ratings up to and including 1.5 and the black squares represent ratings of 5.1 and over.
TABLE VI. Calculation of Theoretical Ratings for Oxygen-Free and Boron-Deoxidized Copper.

Equation form, where $r=$ Calculated rating:

$$
\begin{aligned}
& r=B_{0}+B_{1} X_{1}+B_{2} X_{2}+B_{3} X_{3}+B_{4} X_{4}+B_{12} X_{1} X_{2} \\
& +\mathrm{B}_{13} \mathrm{X}_{1} \mathrm{X}_{3}+\mathrm{B}_{14} \mathrm{X}_{1} \mathrm{X}_{4}+\mathrm{B}_{23} \mathrm{X}_{2} \mathrm{X}_{3}+\mathrm{B}_{24} \mathrm{X}_{2} \mathrm{X}_{4} \\
& +\mathrm{B}_{34} \mathrm{X}_{3} \mathrm{X}_{4}+\mathrm{B}_{11} \mathrm{X}_{1}{ }^{2}+\mathrm{B}_{22} \mathrm{X}_{2}{ }^{2} \\
& \begin{array}{l}
\mathrm{B}_{0}=4.8253 \\
\mathrm{~B}_{1}=0.3285 \\
\mathrm{~B}_{2}=0.2829 \\
\mathrm{~B}_{3}=1.0049 \\
\mathrm{~B}_{4}=0.2857 \\
\mathrm{~B}_{12}=0.0133 \\
\mathrm{~B}_{13}=-0.1206
\end{array} \\
& \mathrm{~B}_{14}=0.0358 \\
& \mathrm{~B}_{23}=-0.2927 \\
& \mathrm{~B}_{24}=-0.1612 \\
& \mathrm{~B}_{34}=-0.2379 \\
& \mathrm{~B}_{11}=-0.1186 \\
& \mathrm{~B}_{22}=0.023 \%
\end{aligned}
$$

$$
\begin{aligned}
X_{1}= & -2 \text { for } 1 \text { nass } \\
-1 & \text { for } 2 \text { passes } \\
& 0 \text { for } 3 \text { passes } \\
& 1 \text { for } 4 \text { passes } \\
& 2 \text { for } 5 \text { passes } \\
X_{3}=-1 \text { for oxygen-free } & \text { copper } \\
& 1 \text { for boron- } \\
& \text { deoxidized copper }
\end{aligned}
$$
$X_{3}=-1$ for oxygen-free copper
1 for boron-
$x_{1}=-?$ for 0 peig* shamber pressure
-1 for 10 psig chamber pressure
0 for 20 psig chamber pressure
1 for 30 rsig shamher pressure
2 for 40 psig chamber pressure

$X_{4}=-1$ for argon shielding gas

1 for helium shielding gas

*(psig - pounds per square inch gauge)

FIGURE 5. Ratings of Gas Tungsten-Arc Welds.

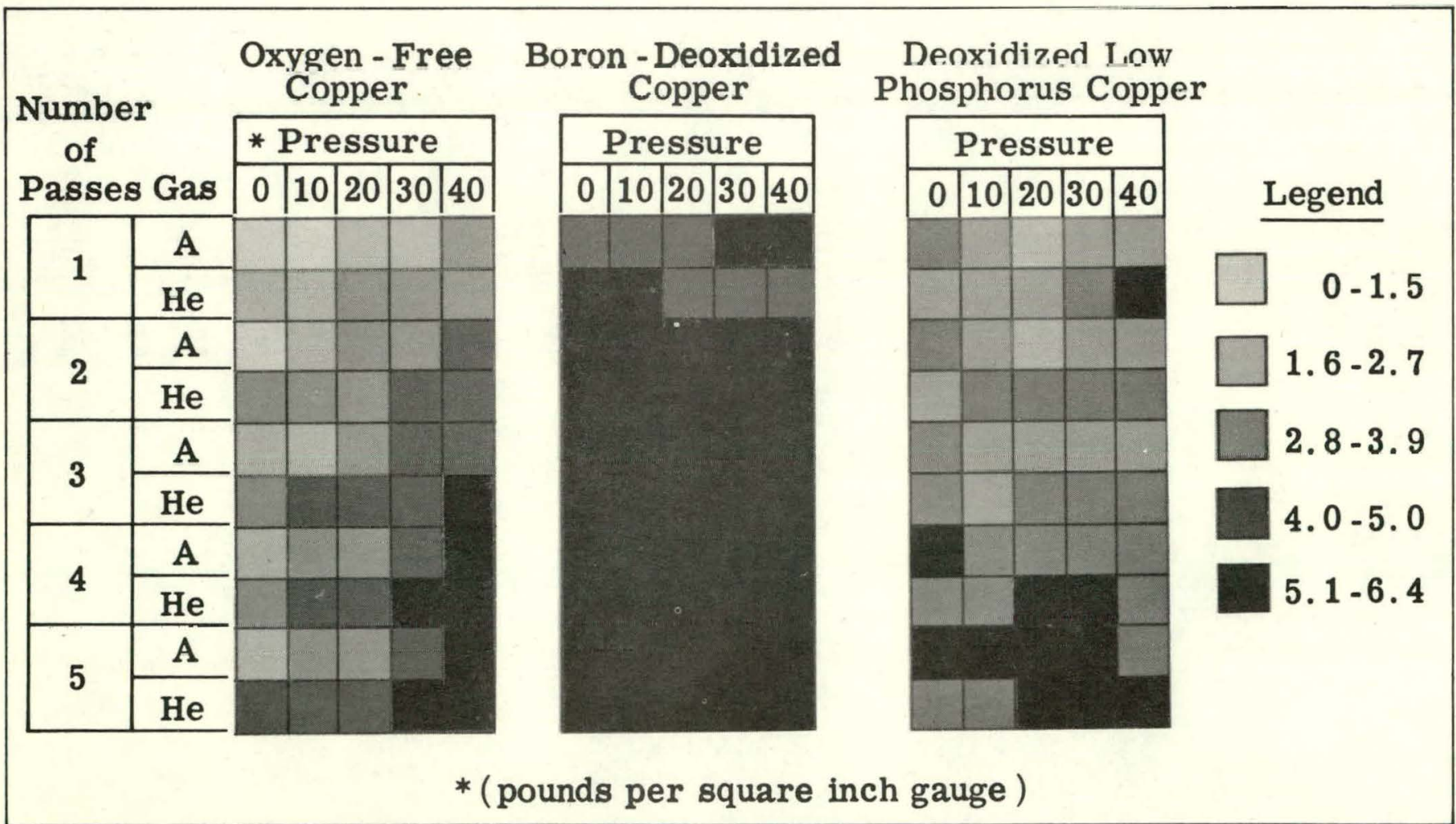


TABLE VII. Calculation of Theoretical Ratings, Deoxidized Low Phosphorus Copper.

Equation form, where $r=$ calculated rating.

$$
\begin{aligned}
& r=B_{0}+B_{1} X_{1} L+B_{2} X_{2}^{L}+B_{3} X_{3}^{L}+B_{4} X_{2} Q+B_{5} X_{3} Q \\
& +B_{6} X_{1} L_{X_{2}} L+B_{7} X_{1} L_{X_{2}} Q+B_{8} x_{1}{ }^{L} X_{3} L+B_{9} X_{1}{ }^{L} X_{3} Q \\
& +\mathrm{B}_{10} \mathrm{X}_{2} \mathrm{~L}_{\mathrm{X}_{3}} \mathrm{~L}+\mathrm{B}_{11} \mathrm{X}_{2} \mathrm{~L}_{\mathrm{X}_{3}} \mathrm{Q}+\mathrm{B}_{12} \mathrm{X}_{2} \mathrm{Q}_{\mathrm{X}_{3}} \mathrm{~L}+\mathrm{B}_{13} \mathrm{X}_{2} \mathrm{Q}_{\mathrm{X}_{3}} \mathrm{Q} \\
& \mathrm{B}_{0}=4.333 \quad \mathrm{~B}_{7}=-0.139 \\
& \mathrm{~B}_{1}=0.222 \quad \mathrm{~B}_{8}=0.500 \\
& \mathrm{~B}_{2}=0.750 \quad \mathrm{~B}_{9}=-0.222 \\
& \mathrm{~B}_{3}=0 \quad \mathrm{~B}_{10}=-0.125 \\
& \mathrm{~B}_{4}=0.083 \quad \mathrm{~B}_{11}=-0.375 \\
& B_{5}=0.167 \quad B_{12}=0.125 \\
& \mathrm{~B}_{6}=-0.250 \quad \mathrm{~B}_{13}=0.042 \\
& \mathrm{X}_{1} \mathrm{~L}=\text { linear effect of shielding gas } \quad=-1 \text { for argon } \\
& +1 \text { for helium } \\
& X_{2}{ }^{L}=\text { linear effect of number of passes }=-1 \text { for } 1 \text { pass } \\
& 0 \text { for } 3 \text { passes } \\
& +1 \text { for } 5 \text { passes } \\
& \mathrm{X}_{2} \mathrm{Q}=\text { quadratic effect of number of passes }=+1 \text { for } 1 \text { pass } \\
& -2 \text { for } 3 \text { passes } \\
& +1 \text { for } 5 \text { passes } \\
& \mathrm{X}_{3}{ }^{\mathrm{L}}=\text { linear effect of chamber pressure }=-1 \text { for } 0 \mathrm{psig} * \\
& 0 \text { for } 20 \text { psig } \\
& +1 \text { for } 40 \text { psig } \\
& -1 \text { for } 40 \text { psig }
\end{aligned}
$$

*(psig - pounds per square inch gauge $)$
There is a pronounced difference in the weldabilities of the three materials. The BD copper exhibited sounder welds over a wide range of variables. Of the BD welds, only 6 of the 50 combinations resulted in welds rated less than 5.1.

Referring to the chart in Figure 5 for the oxygenfree copper, the darker shading of the higher passes (higher pressure corner) indicates the increased soundness of these welds. Conversely, the lowpasses (low-pressure corner) show lower weld soundness. Another trend is also evident. The helium bands are darker indicating that this gas would be preferred.

Regarding the DLP copper chart (Figure 5), a slight improvement in weld quality with greater number of passes is evident. Neither chamber pressure nor type of gas appears to be significant.

Since most of the BD weld ratings occur in one group, any trends are obscured in the BD chart of Figure 5. The BD chart is reproduced in Figure 6 using four shades of gray representing ratings from 4.7 to 6.4 . While all the welds are nearly sound, the diminished size of the groupings serves to emphasize the trends. The use of multiple welding passes appears to improve the weld quality. There is also an interrelationship between chamber pressure and type of shielding gas. At low pressures ( 0 to $20 \mathrm{psig}$ ), helium gives sounder welds; at higher pressures (30 to $4.0 \mathrm{psig}$ ), argon results in sounder welds.

TABLE VIII. Calculated Ratings of Gas Tungsten-Arc Welds in Copper.

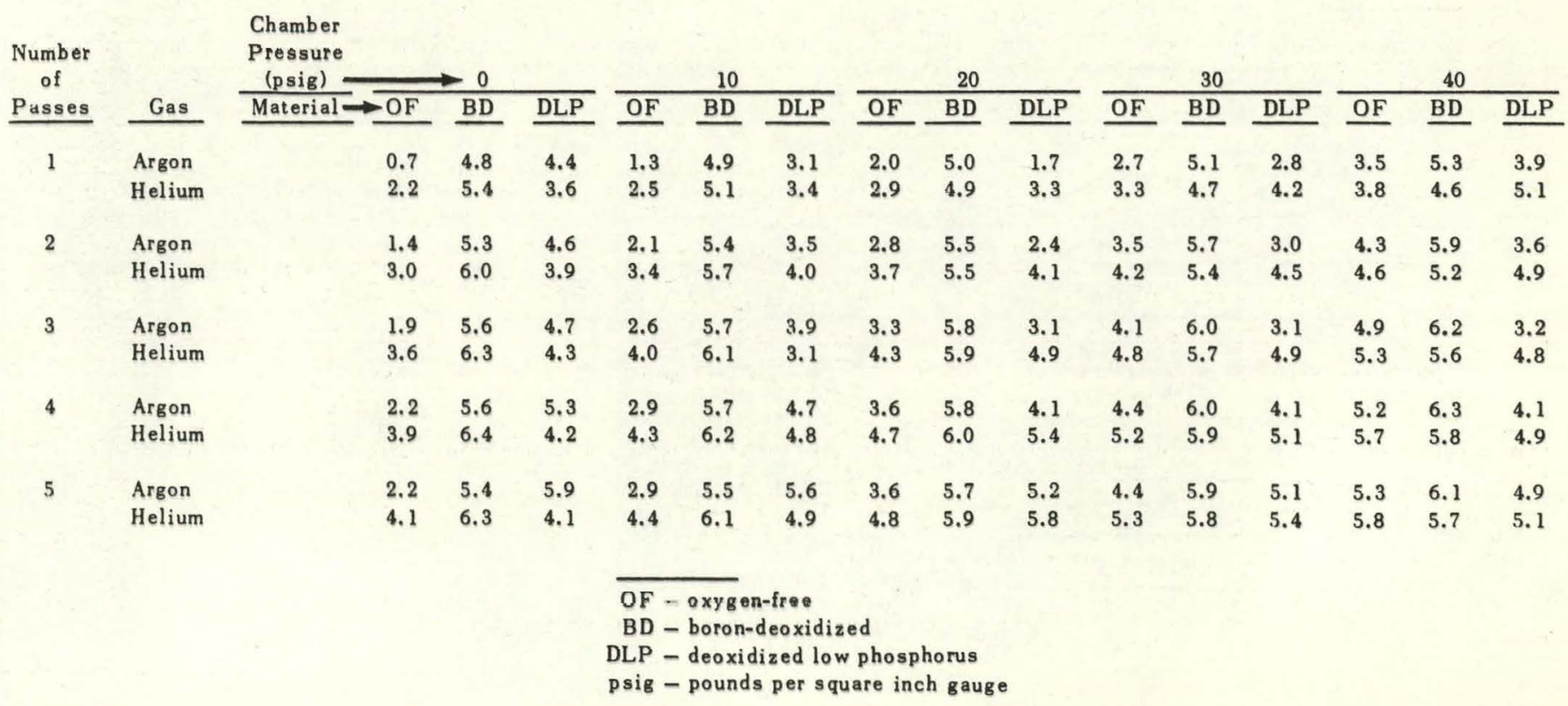


For purposes of examining the data in more detail, the analyses of variance listings are presented in Table IX. Basically, the table apportions the total variability of the ratings into the amount that is

TABLE IX. Results of Analyses of Variances.

Oxygen-Free and Boron-Deoxidized Copper Welds.

$\begin{array}{lr}\text { Source of Variation } & \text { Mean Square } \\ \text { Material } & \\ \text { Number of Passes } & 06.3 \\ \text { Pressure and Material } & 23.3 \\ \text { Shielding Gas } & 20.8 \\ \text { Chamber Pressure } & 12.2 \\ \text { Material and Gas } & 7.7 \\ & 7.0\end{array}$

Significant mean square at 0.05 level of significance $=6.42$.

Deoxidized Low Phosphorus Copper Welds:

Source of Variation

Mean Square

Number of Passes

Significant mean square at 0.05 level of significance $=3.90$. due to each of the possible sources. The individual parameters and cross products which account for 95 percent of the variability are also included. As noted in the table, the higher the mean squares terms, the more significant that element is in affecting the rating.

The choice of material is the most influential variable. The boron-deoxidized copper exhibited substantially better weldability. This is obvious from the shaded rating charts of Figures 5 and 6. Except for the one-pass welds, each combination of variables resulted in BD welds rated at 5.1 or over. Only at combinations of high pressure and multiple passes does the soudness of the $\mathrm{OF}$ and DLP copper approach that of the BD welds. Over the complete rating chart given in Table VIII, the $\mathrm{OF}$ weld ratings ranged from 0.7 with 1 pass, 0 psig pressure, and argon gas to 5.8 with 5 passes, 40 psig pressure, and helium. The BD copper weld ratings ranged from 4.6 with 1 pass, 40 psig pressure, and helium to 6.4 with 4 passes, 0 psig pressure, and helium gas. The DLP weld ratings ranged from 1.7 with 1 pass, 20 psig pressure, and argon gas to 5.9 using 5 passes, 0 pressure, and argon gas.

FIGURE 6. Boron-Deoxidized Copper.

\section{Boron-Denxidized \\ Copper}

\begin{tabular}{|c|c|c|c|c|c|c|}
\hline \multirow{2}{*}{$\begin{array}{c}\text { Number of } \\
\text { Passes }\end{array}$} & \multirow{2}{*}{$\begin{array}{c}\text { Shielding } \\
\text { Gas }\end{array}$} & \multicolumn{5}{|c|}{ * Pressure } \\
\hline & & 0 & 10 & 20 & 30 & 40 \\
\hline \multirow{2}{*}{1} & Argon & & & & & \\
\hline & Helium & & & & & \\
\hline \multirow{2}{*}{2} & Argon & & & & & \\
\hline & Helium & & & & & \\
\hline \multirow{2}{*}{3} & Argon & & & & & \\
\hline & Helium & & & & & \\
\hline \multirow{2}{*}{4} & Argon & & & & & \\
\hline & Helium & & & & & \\
\hline \multirow{2}{*}{5} & Argon & & & & & \\
\hline & Helium & & & & & \\
\hline
\end{tabular}

Legend

* (pounds per square inch gauge) 
The results of this investigation can be plotted graphically as noted in Figures 7, 8, and 9. The curves show weld rating as a function of both number of passes and chamber pressure. In Figure 7, the equal-rating contours show the beneficial effect of using multiple passes and elevated chamber pressure for minimizing porosity of OF copper. Within the scope of this investigation, the best welds resulted from the use of 5 passes and 40 psig pressure. Reducing either the number of passes or the pressure resulted in. decreased weld soundness. Also, helium is preferred over argon since fewer passes or lower pressure is required to produce welds of equivalent soundness. Or, using the same combination, higher quality welds can be made with helium.

Figure 8 shows similar curves for boron-deoxidized copper. In this case, however, there is an inverse relationship between chamber pressure and weld soundness when helium is used. The highest quality welds were produced at atmospheric pressure and 4 passes with helium. Increasing or decreasing the number of passes from 4 resulted in a tendency for lower quality welds.
However, with argon shielding gas, the use of increased pressure did increase the weld soundness. A chamber pressure of 30 psig was required to produce a:weld rating of 6.0 . The optimum number of passes with argon is in the range of 3 to 4 .

Above and below this range, weld quality diminishes.

Figure 9 shows similar curves for the DLP copper. In general, this graph illustrates the beneficial effect of multiple weld passes. With both gases, weld quality increases as up to 5 passes were used.

With argon, the best welds were made at atmospheric pressure and 5 passes. With helium, the best welds were made at 20 to $30 \mathrm{psig}$ chamber pressure and 5 passes.

The raw data from the electron-beam welding tests (given in Table V) were also treated using regression analysis. Again, the choice of material was the most significant factor with boron-deoxidized copper exhibiting significantly sounder welds. As can be seen in Table V, sound electron-beam welds were made in the BD copper at all levels of number of passes from 1 through 4.

FIGURE 7. Rating as Function of Passes and Pressure for Oxygen-Free Copper.

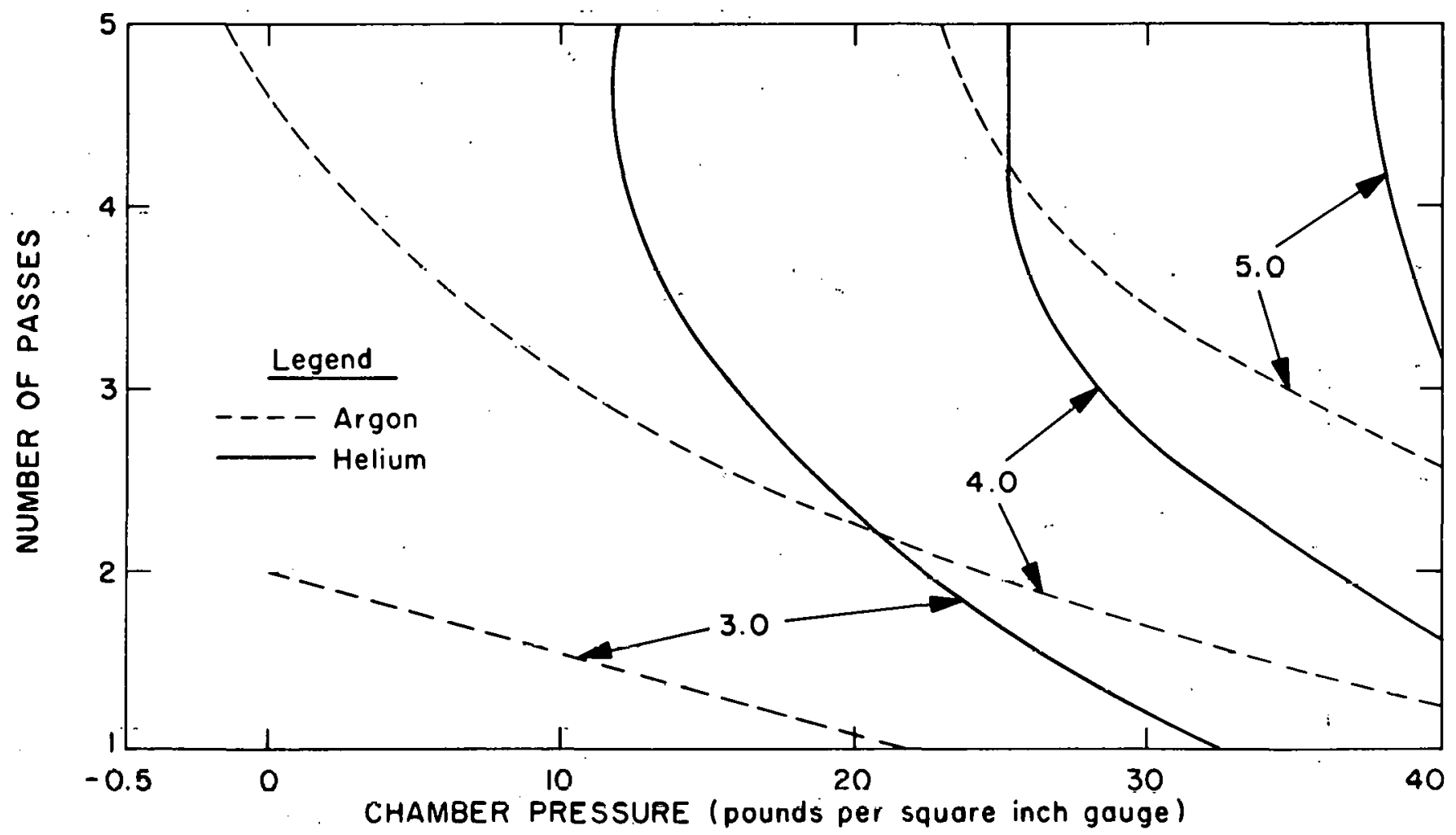


RFP-1106

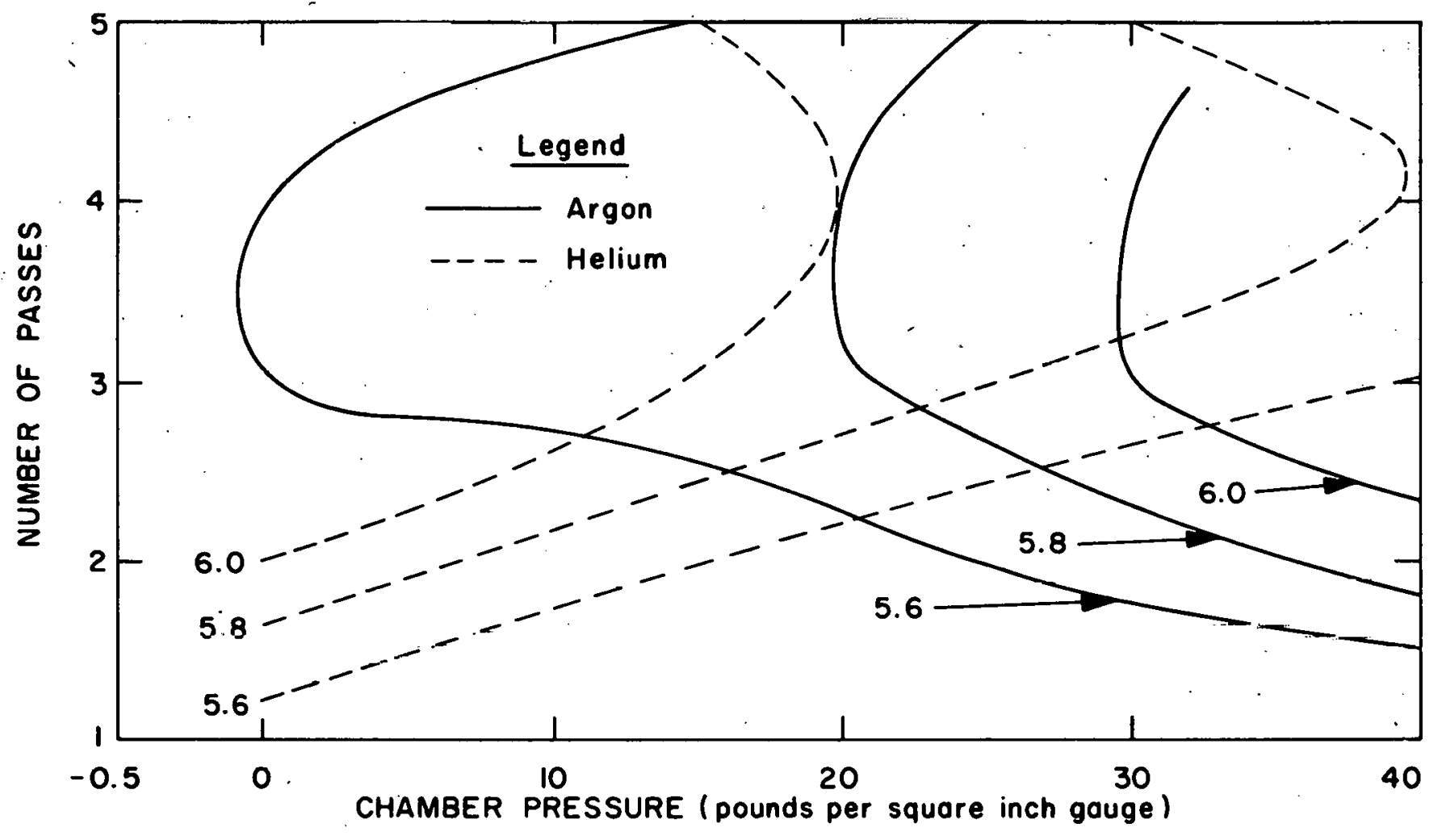

FIGURE 8. Rating as Function of Passes and Pressure for Boron-Deoxidized Copper.

FIGURE 9. Rating as Function of Passes and Pressure for Deoxidized Low Phosphorus Copper.

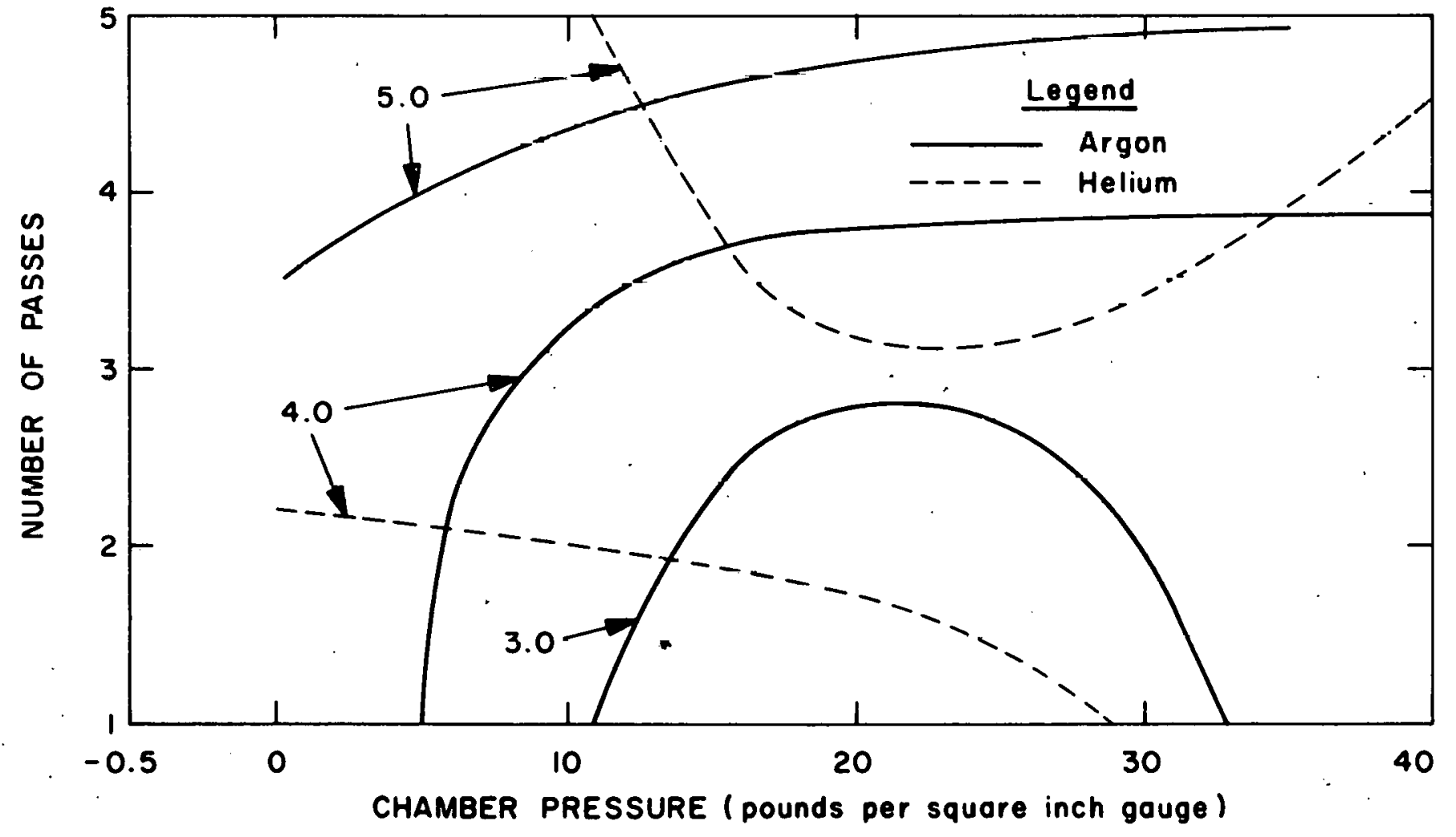


With the oxygen-free copper, the soundness of the welds increased with number of passes. Average ratings of 1.5 resulted with 1 pass and 5.0 with 4 passes.

\section{DISCUSSION}

For purposes of selecting an optimum combination of welding parameters, the graduated shading charts of Figures 5 and 6 and the equal-rating contour curves of Figures 7, 8, and 9 are used. These figures, of course, show the same information but can be used for other purposes.

Suppose a copper weld of maximum soundness is required. Obviously of the three materials considered, boron-deoxidized copper would be chosen. Helium shielding gas would be selected so that the welding could be performed at atmospheric pressure. Four welding passes would be used.

If oxygen-frec copper were required, elevated pressure and multiple passes would be preferred. Within the scope of this investigation, 5 passes and 40 psig pressure gave the best quality welds. In cases where welding under pressure was not possible, the use of helium and multiple passes would give maximum quality welds at atmospheric pressure.

It is important to realize that this investigation was conducted under a particular set of conditions. The results obtained are not universally applicable. For example, the time and temperature during welding are significant in copper welding. During the multiple pass welding repurted herein, a 10minute interpass cooling period was used for standardization. If continuous multiple passes were employed, fewer passes would be required to produce welds of equivalent soundness.

\section{CONCLUSIONS}

1. Porosity-free welds can be produced in OF, BD, and DLP copper by the gas tungsten-arc welding process. Porosity-free welds can be made in $\mathrm{OF}$ and $\mathrm{BD}$ by the electron-beam process. In this investigation, DLP was not clectron-beam welded.
2. Of the four primary variables considered to produce sound gas tungsten-arc welds, the choice of material is the most influential factor. In decreasing order of significance were number of welding passes, shielding gas, and chamber pressure. Interrelationships of material and pressure and also material and shielding gas were found also to be important.

3. For maximum reliability in producing sound GTA welds, the following combination of variables would be selected:

BD copper

Four passes

Helium shielding gas

Atmospheric pressure

4. For the GTA welding of oxygen-free copper the following combination would be selected for welds of maximum soundness:
OF copper
Five passes
Helium shielding gas
40 psig pressure

5. For GTA welding DLP copper, welds of maximum soundness would be made using:
DLP copper
Five passes
Argon shielding gas
Atmospheric pressure

6. The poorest combination for GT'A welding OF copper would be to weld at atmospheric pressure with one pass using argon shielding gas. With DLP copper, the poorest combination would be to weld at 20 psig with argon gas using one pass.

7. With electron-beam welding, sound welds in boron-deoxidized copper can be made with one pass. However, for oxygen-free copper, at least four passes are required to produce welds which approach sound quality.

8. Since either process produces porosity-free welds, choice of process would depend primarily on other factors such as availability of equipment and joint configuration. 